\title{
IMPACT WORKSHOP DESAIN PEMBELAJARAN \\ OLEH CENTER FOR TEACHING STAFF DEVELOPMENT (CTSD) TERHADAP PENINGKATAN PROFESIONALISME DOSEN
}

\author{
Yayan Suryana, Sekar Ayu Aryani, Irsyadunnas \\ UIN Sunan Kalijaga Yogyakarta \\ yayan.suryana@uin-suka.ac.id, sekarayu1826@gmail.com, irsyadbuya@yahoo.com
}

\begin{abstract}
Abstrak
Pembelajaran di perguruan tinggi adalah pembelajaran orang dewasa yang mengantarkan pembelajar pada kehidupan nyata di masyarakat. Oleh karena itu, seyogianya pembelajaran dirancang untuk membekali pembelajar berkarya atau bekerja di dunia nyata dan dirancang sebagai adult learning. Secara umum alumni Workshop Desain Pembelajaran di Perguruan Tinggi oleh Center For Teaching Staff Development (CTSD) mengungkapkan bahwa workshop itu menyenangkan, inspiratif, dan membantu mereka untuk meningkatkan profesionalisme dosen, terutama di bidang paedagogik. Secara umum alumni workshop, pemangku kepentingan/pengguna maupun fasilitator mengharap CTSD ke depan lebih meningkatkan kiprah dan keterlibatannya di UIN Sunan Kalijaga.
\end{abstract}

Kata kunci: pembelajaran, adult learning, profesionalisme

\section{THE IMPACT OF LEARNING DESIGN WORKSHOP CONDUCTED BY CENTER FOR TEACHING STAFF DEVELOPMENT (CTSD) ON THE IMPROVEMENT OF TEACHING PROFESSIONALISM}

\author{
Yayan Suryana, Sekar Ayu Aryani, Irsyadunnas \\ UIN Sunan Kalijaga Yogyakarta \\ yayan.suryana@uin-suka.ac.id, sekarayu1826@gmail.com, irsyadbuya@yahoo.com
}

\begin{abstract}
Learning in college is learning that sends adult learners in real life in the community. Therefore, learning should be designed to equip learners take part or work in the real world and is designed as adult learning. The former participants of Learning Design Workshop in Higher Educational Institution conducted by Center for Teaching Staff Development (CTSD) revealed that the workshop was fun, inspiring, and helping them to improve the professionalism of teachers, especially in the field of pedagogy. Generally, the alumni of the workshop, stakeholders/users, and trainers hope that CTSD can improve its involvement further in UIN Sunan Kalijaga.
\end{abstract}

Keywords:learning, adult learning, profesionalisme 



\section{Pendahuluan}

Pembelajaran di Perguruan Tinggi memiliki karakteristik yang berbeda dengan pembelajaran di jenjang pendidikan menengah atau dasar karena subjek belajar di Perguruan Tinggi relatif sudah memiliki pengetahuan dan pengalaman. Perguruan Tinggi merupakan jenjang pendidikan tertinggi atau jenjang terakhir menuju dunia kerja atau masyarakat yang bertugas menyiapkan subjek didik dengan berbagai kemampuan dan keterampilan untuk bekerja atau berkarya di dunia nyata atau masyarakat. (Tim Kemendiknas, 2010, p. 11). Oleh karena itu, desain pembelajaran di Perguruan Tinggi disebut sebagai pembelajaran orang dewasa (adult learning) yang memiliki desain berbeda dengan sekolah menengah atau dasar.

Dalam merespons berbagai karakteristik tersebut, berbagai rujukan digunakan oleh Center for Teaching Staff Development (CTSD) Universitas Islam Negeri Sunan Kalijaga untuk merancang workshop pengembangan desain pembelajaran di Perguruan Tinggi, mulai dari filosofi mengajar, pengembangan capaian pembelajaran, materi (concept map), strategi pembelajaran, serta evaluasi pembelajaran. Didasari dengan berbagai pengetahuan serta pengalaman kerja sama dengan Center for University Teaching and Learning (CUTL) McGill University Kanada, dirancanglah Workshop Desain Pembelajaran untuk dosen yang telah diikuti ribuan dosen dari berbagai perguruan tinggi di Indonesia, khususnya dosen Perguruan Tinggi Islam di seluruh Indonesia.

Karena kegiatan workshop ini sudah berlangsung cukup lama, yaitu sejak 1998, perlu dilakukan evaluasi terhadap peningkatan profesionalisme dosen yang menjadi peserta workshop tersebut. Tulisan ini berupaya mengungkap (i) hal yang mendasari dirancangnya Workshop Desain Pembelajaran di Perguruan Tinggi oleh CTSD; (ii) rancangan Workshop Desain Pembelajaran dalam memfasilitasi berbagai karakteristik pembelajaran di perguruan tinggi; (iii) perasaan dan pengalaman peserta maupun fasilitator dalam mengikuti workshop ter- sebut; (iv) hal yang diperoleh peserta maupun fasilitator dari workshop ini terkait dengan profesionalisme dosen.

Untuk mengungkap keempat persoalan di atas dapat dirujuk beberapa teori yang dapat membantumenganalisis data, di antaranya Patricia Cranton yang menjelaskan mengenai empat hal pokok dalam mendesain pembelajaran, yaitu desain materi, tujuan, strategi dan evaluasi. Sesuai dengan judulnya, tahapan desain komponen pokok tersebutdibuat lebih terbuka, fleksibel dan partisipatif mengingat audiensnya adalah pembelajar orang dewasa (adult learner) (Cranton, 1995, p. 30). Dalam buku Cranton yang lain, dipaparkan secara lebih lengkap ciri keterbukaan, fleksibel, dan partisipatif ini (Cranton, 1992, p. 87).

Sementara itu, tentang strategi mengajar yang disarankan untuk Perguruan Tinggi dirujuk beberapa buku seperti McKeachie (1994, p. 125) dan Silberman (1996). Keduanya memberikan berbagai tawaran strategi untuk memfasilitasi pembelajar yang tujuan belajarnya lebih ke arah menyiapkan diri untuk mampu mengerjakan keterampilan tertentu. Pilihan strategi active learning, yang mengundang partisipasi pembelajar, membuat memori lebih kuat, problem solving, serta strategi lain yang sesuai dengan pembelajar orang dewasa dibahas di sini.

Terkait dengan konteks Indonesia, dirujuk pula kebijakan pemerintah yang diberlakukan, seperti Standar Nasional Pendidikan Tinggi (SNPT) yang memuat berbagai standar untuk menjamin terselenggaranya pembelajaran yang bermutu di Perguruan Tinggi. Kebijakan ini meliputi standar isi, standar proses, serta standar evaluasi. Disamping itu, Kerangka Kualifikasi Nasional Indonesia (KKNI) juga digunakan untuk mengukur seberapa sesuai pembelajaran yang dirancang dalam workshop ini untuk memfasilitasi ekspektasi dari penjenjangan yang ada dalam KKNI.

\section{Metode Penelitian}

Penelitian ini dirancang dalam bentuk survei. Populasi dan sampel dalam sur- 
vei ini ialah alumni workshop CTSD yang jumlahnya sudah mencapai 3000 orang dan tersebar di seluruh Indonesia. Namun, karena berbagai keterbatasan, maka peneliti memilih sebanyak 27 orang untuk responden kuesioner dari pihak alumni dari berbagai Fakultas dan Perguruan Tinggi yang terjangkau, 9 dari pengguna termasuk pimpinan dan 7 orang dari staf CTSD. Sedang interview dilakukan terhadap dua pengguna dari kalangan pimpinan baik Fakultas maupun Universitas. Teknik sampling yang digunakan double sampling yaitu cluster dan puposive sampling

Pengumpulan data dilakukan dengan menyebarkan kuesioner terbuka yang diikuti dengan wawancara untuk mendalami informasi yang telah terkumpul melalui kuesioner. Infomasi lain diperoleh melalui dokumentasi tertulis yang diperoleh baik dari buku, brosur, profile atau lembar penduan workshop yang digunakan CTSD. Data yang telah terkumpul kemudian dianalisis secara kualitatif melalui proses reduksi, displai, dan verifikasi data, kemudian dilakukan penarikan kesimpulan.

\section{Hasil Penelitian dan Pembahasan}

Profil Center for Teaching Staff

Development (CTSD)

Sejarah pembentukan CTSD tidak dapat dipisahkan dengan kerja sama antara pemerintah Indonesia dengan Kanada dalam proyek kerja sama antara IAIN dan McGill Uiversity, Montreal, dengan nama Indonesia-Canada Islamic Higher Education Project (ICIHEP) pada 1990. Awalnya ialah kerja sama dalam bidang studi keislaman atau Islamic Studies dalam bentuk pengiriman dosen-dosen IAIN dari seluruh Indonesia ke Kanada untuk melanjutkan studi S2 dan S3 dalam Islamic Studies di McGill University, Montreal (Zaini et al, 2003, p. ix).

Kerja sama IAIN-McGill University berlanjut pada tahun 1995 untuk fase yang kedua. Hasil dari kerja sama IAIN-McGill University fase kedua yang diperluas ini, pada tahun 1996 dilaksanakan Workshop
Pendidikan untuk dosen-dosen IAIN dari seluruh Indonesia. Workshop ini dilaksanakan oleh Centre for University Teaching and Learning (CUTL), McGill University dengan materi desain instruksional yang berlangsung selama enam bulan (Zaini et al, 2003, p. x). Pendekatan yang dikembangkan oleh para faculty developer (fasilitator/narasumber) CUTL dalam workshop pengembangan kualitas pembelajaran di perguruan tinggi tersebut adalah pendekatan pembelajaran orang dewasa (adult learning).

Para faculty developer CUTL McGill University juga mengkader beberapa orang untuk mampu menggantikan peran mereka pada masa yang akan datang. Pada workshop tahun 1996, mereka melaksanakan tujuan tersebut dengan difasilitasi empat penerjemah dari IAIN Sunan Kalijaga, yaitu Susilaningsih, Bermawy Munthe, Siti Ruhaini Dzuhayatin, dan Hisyam Zaini. Pada workshop kedua tahun 1997, tiga dari empat penerjemah tersebut dipilih menjadi ko-instruktur (Zaini et al, 2003, p. x). Selanjutnya, mereka diberi pelatihan tambahan berupa pendalaman materi dengan mengkaji bersama tim McGill buku-buku literatur pokok tentang Higher Education kurang lebih selama seminggu dalam setiap semester selama dua tahun. Pelatihan tersebut dilakukan di Indonesia dan Kanada. Dari serangkaian pengkaderan ini, baik berupa menjadi ko-instruktur dalam workshop, maupun pelatihan pendalaman (Training Stage) ini Faculty Developer dari Indonesia ini mendapat tujuh sertifikat internasional dari Faculty of Education McGill University sebagai tanda garansi pemberian izin memberi workshop sebagaimana yang disampaikan tim CUTL McGill dalam Workshop on Higher Educationnya.

Setelah melalui serangkaian kegiatan tersebut, pada 1996 didirikanlah Pusat Pengembangan Pengajaran di IAIN Sunan Kalijaga. Pusat pengembangan tersebut didirikan dengan SK Rektor dan diberi nama Center for Faculty Development. Pada 1997 nama tersebut dikembangkan menjadi Center for Teaching Staff Development (CTSD) (Zaini et al, 2003, p. x). Pada tahun 
1998, empat orang yang pernah menjadi ko-instruktur para faculty developer McGill University mendapat kesempatan untuk menimba ilmu tentang faculty development di Kanada sehingga mereka dapat melakukan kunjungan ke University of British Columbia, Simon Fraser University, McGill University, University of Alberta dan beberapa perguruan tinggi lainnya (Zaini et al, 2003, p. x). CTSD sudah memfasilitasi ratusan kali workshop yang diberi nama Workshop Desain Pembelajaran. Selain workshop tersebut, CTSD juga telah memfasilitasi berbagai workshop antara lain, Workshop Desain Pembelajaran di Perguruan Tinggi, TOT Desain Pembelajaran, TOT Sukses di Perguruan Tinggi, Workshop Redesain Kurikulum, Workshop Redesain Kurikulum merujuk KKNI dan SNPT, Workshop Desain Pembelajaran merujuk KKNI dan SNPT, Workshop Redesain RPS/Silabi, Workshop Strategi Pembelajaran Aktif, Workshop Calon Dosen UIN Sunan Kalijaga, Workshop Kompetensi Kepribadian, Profesional, Sosial, danPaedagogik bagi calon-calon dosen UIN Sunan Kalijaga, Workshop Pengembangan Mahasiswa Bidik Misi, Workshop EQ, dan Workshop Penulisan Jurnal Ilmiah. Belakangan Workshop Desain Pembelajaran ini juga disesuaikan dengan Kerangka Kualifikasi Nasional Indonesia (KKNI) serta Standar Nasional Pendidikan Tinggi (SNPT) sebagaimana yang menjadi regulasi Kementerian Ristek dan Pendidikan Tinggi.

Empat orang Faculty Developer yang dikader McGill diatas yaitu Bermawy Munthe, Sekar Ayu Aryani, Siti Ruhaini Dzuhayatin, dan Hisyam Zaini berstatus sebagai member (anggota tetap) di CTSD. Merekalah secara bergilir memiliki hak untuk memimpin CTSD, (AD dan ART CTSD). Pada kepengurusan tahun 2015, tim CTSD UIN Sunan Kalijaga adalah Prof. Dr. Bermawy Munthe, MA (Kepala), Adib Sofia, SS., M.Hum (Wakil Kepala), Roni Ismail, S.Th.I., M.S.I. (Sekretaris), Dr. Sekar Ayu Aryani, MA. (Anggota), Dr. Hisyam Zaini, MA (Anggota), Dr. Eva Latipah,
M.Si. (Anggota), Dr. Irsyadunnas (Anggota),Diah Ajeng Purwani, M.Si. (Anggota).

Sebelum tim di atas, beberapa orang yang pernah terlibat sebagai pengelola CTSD dan sekaligus sebagai trainer, yaitu Dr. Ruhaini Dzuhayatin, MA, Dra. Hj. Susilaningsih, M.A., Prof. Dr. H. Hamruni, M.Si., Drs. Djamroh Latief, M.Si., Dr. Mardjoko Idris, MA, Dr. Sembodo Ardi Widodo, M.Ag., Ahmad Muttaqin, M.Ag., MA., Ph.D., dan Dr. Casmini. Dalam perekrutan kepengurusan di atas CTSD senantiasa berkonsultasi kepada Rektor. Baik CTSD maupun pimpinan UIN Sunan Kalijaga selalu berusaha mengangkat pengurus yang merepresentasikan Fakultas yang ada di UIN Sunan Kalijaga.

Terkait dengan pengembangan dosen ini pula, pada periode kepemimpinan Rektor Prof. Dr. Amin Abdullah, CTSD juga diberi kepercayaan menangani dosendosen yang kinerja mengajarnya kurang baik berdasarkan angket penjaminan mutu dan menangani Training of Trainer (TOT) bagi dosen yang akan menjadi fasilitator dalam Workshop Sosialisasi Pembelajaran (Sospem) bagi mahasiswa baru. Bahkan sejak konversi IAIN ke UIN Sunan Kalijaga sampai sekarang CTSD pun selalu diminta keterlibatannya dalam kegiatan Redesain Kurikulum baik di Prodi, Fakultas bahkan Universitas, dikecualikan Fakultas yang sudah tidak membutuhkan bantuan lagi karena bidang keahliannya terkait dengan kurikulum, seperti Fakultas Tarbiyah.

\section{Workshop Desain Pembelajaran CTSD}

Kegiatan Workhsop Desain Pembelajaran yang difasilitasi oleh CTSD UIN Sunan Kalijaga memiliki beberapa dasar pemikiran (Munthe et al, 2008, pp. 44-45) yaitu pertama, pendidikan dan pengajaran adalah satu dari tiga elemen Tri Dharma perguruan tinggi. Kedua, Undang-Undang Guru/ Dosen No. 14 Tahun 2005 menuntut karakter guru/dosen yang kompeten dalam pembelajaran/pedagogis (Depdiknas, 2005). Ketiga, kualitas (quality) tidak pernah terjadi secara kebetulan. Keempat, peningkatan kualitas profesionalisme mengajar dosen tampaknya untuk proses pembel- 
ajaran mahasiswa kurang atau belum mendapat kepedulian (concern) pendidikan tinggi. Kelima, pelaksanaan Kurikulum Berbasis Kompetensi (Competency Based Curriculum). Keenam, kenyataan mengatakan bahwa mayoritas dosen yang mengajar di perguruan tinggi bukan berlatar belakang ilmu keguruan atau kependidikan. Ketujuh, kecakapan (skill) pelayanan pembelajaran orang dewasa (andragogi) adalah satu seni yang menuntut penguasaan kerangka teori, konsep, metode, strategi atau tehnik pembelajaran. Kedelapan, tuntutan mahasiswa terhadap kualitas pelayanan pembelajaran satu keharusan. Kesembilan, instrumen-instrumen sertifikasi dosen/guru menuntut pembuktian yang akurat: jujur, samanah/trust, profesional dan cerdas tetapi juga dapat diukur, dapat dievaluasi, dapat dibuktikan berdasarkan pengalaman dan pengetahuan seorang dosen. Kesepuluh, sebuah Course Outline atau out-line mata kuliah adalah bukti objektif tertulis (Quality Assurance) seorang dosen terhadap mata kuliahnya. Kesebelas, Perpres Nomor 8 tahun 2012 tentang KKNI, Permendikbud Nomor 73 tahun 2013 tentang Penerapan Kerangka Kualifikasi Nasional Indonesia bidang Pendidikan Tinggi, dan Permendikbud Nomor 49 tahun 2014 tentang Standar Nasional Pendidikan Tinggi, arti penting workshop Desain Pembelajaran yang sudah dilaksanakan oleh CTSD selama belasan tahun memiliki pijakan yuridis-formalnya secara nyata.

Workshop ini diadakan untuk mencapai target kualifikasi dosen profesional yang memadai dalam rangka meningkatkan kualitas pembelajaran. Diantara target yang ingin dicapai dari workshop pembelajaran ini adalah para peserta workshop mampu: (1) mendesain materi kuliah/ Standar Isi Pembelajaran (istilah dalam SNPT) dengan teknik peta konsep (conceptmap); (2) mendesain sejumlah kompetensi (Competency) atau tujuan pembelajaran (Learning Objectives)/Standar Kompetensi Lulusan (istilah dalam SNPT) yang sesuai dengan materi kuliah; (3) mendesain berbagai strategi pembelajaran (instructional strategies) /Standar Proses Pembelajaran (istilah dalam SNPT) yang sesuai dengan materi kuliah dan kompetensi atau tujuan pembelajaran; (4) mendesain evaluasi pembelajaran/Standar Penilaian Pembelajaran (istilah dalam SNPT) yang mengaplikasikan prinsip dan teknik yang fair, yang sesuai dengan materi kuliah, kompetensi, dan strategi pembelajaran; (5) membuat satu out-line matakuliah atau Satuan Acara Perkuliahan secara holistik; (6) membuat satu Silabus/Rencana Pembelajaran Semester (RPS dalam istilah SNPT) baru;

Berdasarkan hasil wawancara dengan alumni Workshop CTSD, Joko Setyono, M. Ghafur Wibowo, dan Slamet, bahwa model pembelajaran dalam Workshop Desain Pembelajaran CTSD berkontribusi pada peningkatan wawasan tentang model pembelajaran. Model-model pembelajaran lebih inovatif dan membuat proses perkuliahan lebih dinamis, serta mampu meningkatkan metode pembelajaran dosen. Workshop Desain Pembelajaran sangat relevan, terutama menyangkut strategi pembelajaran dan pembenahan kurikulum, memberikan bekal bagi dosen baru yang belum mengenal paedagogik.

Dilihat dari materi pelatihan, workshop desain pembelajaran CTSD relevan untuk kesiapan kinerja dosen, sebab menurut Miftahun Ni'mah S. dan Sulistyaningsih (Dosen FISHUM UIN Suka) meng$\mathrm{aku}$, setelah mengikuti workshop merasa lebih siap dalam proses pembelajaran di kelas, workshop betul-betul memberi kompetensi dalam teaching skill bagi dosen, khususnya dosen-dosen muda.

Sementara itu, menurut Muhammad Yusup, Dian Nur Anna (dosen Fakultas Ushuluddin dan Pemikiran Islam), Suwadi, Dudung Hamdun, (Dosen Fak. Tarbiyah dan Keguruan) M. Rudi Nugroho, Siti Nur Azizah, Rasyid Nur Anggar, Lailatis Syarifah, Mufiatun, dan Yayu Putri Senjani, (dosen FEBI) UIN Sunan Kalijaga, strategi pembelajaran yang ditawarkan CTSD dalam mendisain pembelajaran berangkat dari basis penyusunan concept map. Hal ini kontributif bagi peningkatan profesionalisme dosen. Strategi ini dinilai olehnya bahwa workshop mampu membuka wa- 
wasan dan memberikan keterampilan khusus bagi dosen yang dilatih.Workshop pembelajaran yang diberikan CTSD juga telah menerapkan model pembelajaran KKNI dan SNPT yang merupakan kurikulum baru yang wajib diterapkan dalam proses pembelajaran di PT.

Pandangan positif mengenai model pembelajaran yang ditawarkan oleh CTSD tidak hanya berasal dari dosen internal UIN, melainkan juga dari beberapa dosen di perguruan tinggi lain, serperti UMY, UAD, dan UMS. Dosen dari UMY menyatakan bahwa materi workshop desain pembelajaran CTSD yang disampaikan sangat relevan dengan kebutuhan dosen, sehingga berbanding lurus dengan peningkatan profesionalisme dosen. Materi asertivitas yang diajarkan dalam workshop desain pembelajaran CTSD banyak membantunya dalam memahami karakteristik mahasiswa dan membuat keputusan (decision making). Hal tersebut menimbulkan kepercayaan diri pada dosen dan memiliki kesiapan dalam mengajar. (Wawancara dengan Naufal Ahmad Rijalul Alam, Halimatussadiyah, dan Anita Aisyah, ketiganya dosen FAI UMY).

Hal senanda diungkapkan oleh dosen dari UMS yang pernah mengikuti workshop, bahwa workshop desain pembelajaran CTSD relevan dengan tuntutan kebutuhan bagi seorang dosen. Materi workshop sesuai dengan tugas utama dosen dalam pendidikan dan pembelajaran. Workshop desain pembelajaran CTSD mampu mengubah pola pikir dunia pendidik yang tadinya searah (pendidikan sangat dominan) menjadi dua pihak yang terlibat (pendidik dan peserta didik) sama-sama membutuhkan. Pola pikir ini sangat penting guna memaksimalkan potensi yang dimiliki peserta didik. Model pembelajaran yang diberikan melalui workshop CTSD mendorong munculnya sikap terbuka dalam pola mengajar, koontributif bagi perubahan perlakuan terhadap mahasiswa. Begitu pula ungkapan dosen-dosen yang UCY yang pernah mengikuti workshop serupa. F. Setiawan Santoso, Hilman Haroen P., M. Nur Kholis, mengungkapkan bahwa workshop desain pembelajaran CTSD sa- ngat relevan dan kontributif dalam peningkatan profesionalisme dosen.

Pandangan tentang relevansi workshop desain pembelajaran CTSD tersebut diperkuat lagi dengan pengakuan mereka tentang apa yang mereka dapatkan dan riifinyang mereka rasakan dari workshop CTSD. Hal tersebut sebagaimana dikemukakan Joko Setyono, dosen Fakultas Ekonomi dan Bisnis Islam UIN Sunan Kalijaga, setelah mengikuti workshop desain pembelajaran CTSD mengaku mendapatkan model pembelajaran yang efektif dan active learning, sementara M. Ghafur Wibowo, dosen FEBI lainnya, mengaku setelah mengikuti workshop desain pembelajaran CTSD, kemampuan mengajarnya menjadi lebih baik. Testimoni yang hampir sama juga diungkapkan oleh Siti Aminah yang mengatakan bahwa workshop desain pembelajaran CTSD meningkatkan keterampilannya dalam mengajar. Sementara Slamet, mengatakan bahwa CTSD mengingatkannya tentang mengajar dan perlunya dosen meningkatkan performance-nya. Sumarsono mengaku setelah mengikuti workshop desain pembelajaran CTSD ia dapat membuat bahan ajar, menerapkan active learning dan strategi pembelajaran dengan baik. Pendapat yang kurang lebih senada juga disampaikan oleh Benny Herlena yang mengaku setelah mengikuti workshop desain pembelajaran CTSD ia memperoleh skill untuk pembelajaran yang berkualitas.

Workshop Desain Pembelajaran yang difasilitasi CTSD UIN Sunan Kalijaga juga dirasakan manfaatnya oleh kalangan guru di Indonesia, seperti di Cirebon, Ngawi, Gorontalo, Yogyakarta, Solo, Sibolga, dan Indramayu. Para peserta Workshop Desain Pembelajaran meluas ke kalangan ustadzustadzah di lingkungan pesantren yang ada di wilayah jawa antara lain di Banten, Yogyakarta, Solo, dan Nganjuk. Bahkan, CTSD pernah memberi workshop tersebut untuk para ustadz/ustadzah pesantren seSolo Raya dalam lima angakatan yang diadakan di Pesangtren Ngruki selama tahun 2013. Bahkan pada tahun 2015, bekerja sama dengan UMS, CTSD menjadi 
fasilitator workshop serupa untuk ustadz/ ustadzah pesantren se-Solo Raya dengan jumlah peserta mencapai dua kelas dalam satu angkatan.

Pendekatan yang digunakan dalam Workshop desain pembelajaran yang diselenggarakan oleh CTSD UIN Sunan Kalijaga tertuang dalam outline workshopnya, yaitu menggunakan pendekatan andragogi yang menjadikan peserta sumber inspirasi dan sharing ideas. Metode diskusi, kolaborasi, dan interactive-lecturing digunakan guna memperkaya pengalaman dan wawasan. Hal penting adalah upaya membangun komunikasi dan feedback yang konstruktif antara sesama peserta. Para fasilitator akan memberikan feedback terhadap kemajuan yang dicapai peserta (Zaini et al, 2003, p. xii). Pada setiap akhir materi, peserta mempraktikkan secara langsung apa yang dipelajari atau micro-teaching. Hasilhasil praktik diarsip dalam portofolio yang kemudian akan dievaluasi dan diberi feedback oleh tim fasilitator dari CTSD UIN Sunan Kalijaga. Setiap peserta mendapat giliran untuk mempraktikkan strategi pembelajaran melalui praktik micro-teaching dan kembali mendapatkan feedback dari fasilitator.

Workshop Desain Pembelajaran dan Peningkatan Profesionalisme Dosen

Dalam Undang-Undangan Nomor 14 Tahun 2005, Tentang Guru dan Dosen Bab I, Pasal 1 ayat 2, profesionalitas dosen diatur dengan prinsip-prinsip tertentu, yaitu (Depdiknas, 2005): (a) memiliki bakat, minat, panggilan jiwa, dan idealisme; (b) memiliki komitmen untuk meningkatkan mutu pendidikan, keimanan, ketakwaan, dan akhlak mulia; (c) memiliki kualifikasi akademik dan latar belakang pendidikan sesuai dengan bidang tugas; (d) memiliki kompetensi yang diperlukan sesuai dengan bidang tugas; (e) memiliki tanggung jawab atas pelaksanaan tugas keprofesionalan; (f) memperoleh penghasilan yang ditentukan sesuai dengan prestasi kerja; (g) memiliki kesempatan untuk mengembangkan keprofesionalan secara berkelanjutan dengan belajar sepanjang hayat; (h) memiliki ja- minan perlindungan hukum dalam melaksanakan tugas keprofesionalan; dan (i) memiliki organisasi profesi yang mempunyai kewenangan mengatur hal-hal yang berkaitan dengan tugas keprofesionalan guru.

Dari prinsip tersebut, CTSD fokus pada prinsip yang keempat (poin d) yaitu "memiliki kompetensi yang diperlukan sesuai dengan bidang tugas". Profesional dalam UU Guru dan Dosen mensyaratkan adanya keahlian, kemahiran, atau kecakapan yang memenuhi standar mutu atau norma tertentu serta memerlukan pendidikan profesi. Keahlian berarti seorang dosen harus menguasai bidang yang diajarkannya kepada mahasiswa. Sementara kemahiran dan kecakapan berarti kemampuan di atas rata-rata dalam mentransformasikan ilmunya. Dengan kata lain, keahlian, kemahiran dan kecakapan adalah kata lain untuk kompetensi.

Secara definitif, kompetensi adalah seperangkat pengetahuan, keterampilan, dan perilaku yang harus dimiliki, dihayati, dan dikuasai oleh guru atau dosen dalam melaksanakan tugas keprofesionalan. Seperangkat pengetahuan tersebut dapat melekat pada diri dosen tidak dicapai dengan cara sederhana, namun dengan serangkaian proses dan beragam upaya.

Posisi Workshop CTSD dalam Pengembangan Profesionalisme Dosen

Upaya agar dosen semakin berdaya dan kompeten, menurut Undang-Undang Nomor 14 Tahun 2005 tentang Guru dan Dosen bab III pasal 7 ayat 2 (Depdiknas, 2005) ditempuh dengan cara pengembangan diri. Pengembangan diri tersebut harus dilakukan secara demokratis, berkeadilan, tidak diskriminatif, dan berkelanjutan dengan menjunjung tinggi hak asasi manusia, nilai keagamaan, nilai kultural, kemajemukan bangsa, dan kode etik profesi. Pada level pengembangan diri inilah CTSD sejauh ini banyak berperan.CTSD melalui berbagai programnya, terutama dengan workshop-workshop yang diselenggarakan, selalu dilakukan sesuai UU tersebut. Nilainilai seperti demokratis, berkeadilan, nondiskriminatif, continous improvement, respek 
pada HAM dan keberagamaan serta keragaman budaya merupakan nilai dasar yang selalu dijunjung tinggi oleh CTSD dalam setiap programnya.

Kontribusi Workshop CTSD dalam Peningkatan Profesionalisme Dosen

CTSD memiliki kontribusi dalam meningkatkan profesionalisme dosen. Kontribusi tersebut di antaranya adalah: memperkenalkan konsep profesionalisme kepada para dosen, memberikan cara meningkatkan profesionalisme, membantu dosen menemukan tujuan profesionalismenya. Peran CTSD untuk memperkenalkan profesionalisme kepada dosen telah mendapat pengakuan dari para alumni dan user yang menjadi responden dalam penelitian ini. Responden memang mengetahui konsep profesionalisme dosen dari berbagai sumber.

Dari beberapa kali workshop yang telah diselenggarakan CTSD, para alumni merasakan berbagai manfaatnya. Manfaat tersebut secara umum dapat dilihat dari testimoni alumni yang berhasil diinventarisasi dalam penelitian ini. Menurut alumni, manfaat workshop CTSD adalah: (1) menjadi inovasi dan alternatif model pembelajaran modern, (2) memberi inspirasi untuk membenahi kurikulum, (3) memudahkan memahami banyak hal dengan keterampilan peta konsep, (4) mengenal andragogi dan pelaksanaannya, (5) menambah rasa percaya diri dosen, (6) semakin mampu membuat keputusan dengan decision making, (7) mempermudah treatment pada mahasiswa melalui keterampilan asertivitas, (8) mengetahui langkah perencanaan hingga evaluasi, dan (9) mengetahui serta bisa menerapkan KKNI dan SNPT dalam proses pembelajaran di perguruan tinggi.

Keterlibatan CTSD dalam Pengembangan Profesionalisme Dosen

CTSD memiliki keterlibatan yang signifikan dalam pengembangan profesionalisme dosen, terutama dalam bidang kompetensi Paedagogik. Hal ini dilakukan baik di UIN Sunan Kalijaga maupun tem- pat lain di berbagai propinsi di Indonesia. Di UIN Sunan Kalijaga sebagai home base, CTSD secara rutin menjadi penggerak utama pelaksanaan Sosialisasi Pembelajaran (SOSPEM) bagi mahasiswa baru setiap tahun ajaran baru. CTSD juga memberikan training kepada dosen-dosen baru yang akan mengabdi di UIN Sunan Kalijaga. Kedua kegiatan tersebut merupakan tugas rutin yang selalu dilaksanakan dengan baik oleh CTSD.

\section{Simpulan}

Berangkat dari persoalan akademik yang diajukan dalam riset ini, dapat ditarik kesimpulan pembelajaran di perguruan tinggi adalah pembelajaran yang mengantarkan pembelajar pada kehidupan nyata di masyarakat. Oleh karena itu, seyogianya pembelajaran dirancang untuk membekali pembelajar berkarya atau bekerja di dunia nyata.Pembelajaran di perguruan tinggi merupakan pembelajaran bagi orang dewasa sehingga CTSD merancang pendekatan dan strategi pembelajarannya dengan adult learning, khususnya yang biasa disebut dengan andragogi.

Alumni workshop desain pembelajaran di perguruan tinggi yang diadakan CTSD, menyatakan perasaan senang, menarik, menyenangkan, nyaman, fun, serius tetapi santai, dan terinspirasi dalam mengikuti workshop tersebut. Pernyataan yang hampir sama diberikan dari pihak fasilitator. Secara umum peserta mengungkapkan bahwa Workshop Desain Pembelajaran di Perguruan Tinggi oleh CTSD membantu mereka untuk meningkatkan profesionalisme dosen, terutama di bidang paedagogik.

\section{Daftar Pustaka}

Cranton, P. (1992). Working with adult learners. Toronto: Wall \& Emerson, Inc.

Cranton, P. (1995). Planning instruction for adult learners. Toronto: Wall \& Emerson, Inc.

Depdiknas. Undang-Undang No. 14 Tahun 2005 tentang Guru dan Dosen (2005). Jakarta. 
McKeachie, W. J. (Ed.). (1994). Teaching tips. Toronto: DC, Heath and Company.

Munthe, B., \& et al. (2008). Desain pengembangan calon dosen. Yogyakarta: UIN Sunan Kalijaga.

Silberman, M. (1996). Active learning: 101 strategies to teach any subject. Toronto: Allyn Bacon.
Tim Kemendiknas. (2010). Panduan pengembangan diri. Jakarta: Depdiknas.

Zaini, H., \& et al. (2003). Desain pembelajaran di perguruan tinggi. Yogyakarta: CTSD IAIN Sunan Kalijaga. 